\title{
THE THREAT OF ALLUVIATION OF LAKES RESULTING FROM TORRENTS (CASE STUDY: LAKE VOLVI, NORTH GREECE)
}

\author{
P. STEFANIDIS, S. STEFANIDIS \& F. TZIAFTANI \\ Institute of Mountainous Water Management and Control, Aristotle University of Thessaloniki, Greece.
}

\begin{abstract}
Lakes or natural reservoirs are usually formed by the water supplied by torrents runoff. Furthermore, runoff, according to the torrential environment that forms the watershed (climate, geology, vegetation and relief) is usually associated with debris flow. As a result, many lakes and reservoirs are undergoing an alluviation process which leads to an important reduction of their total capacity. In fact, long-term process of torrents may threaten their existence. Lakes and reservoirs have an important role since the impounding water is used for multi purposes such as municipal supply, irrigation and recreation. Often, lakes form wetlands that are really important and are protected by national or international treaties. In this paper, the methodology we use involve the analysis of torrential environment (potential) of the lake Volvi watershed. Moreover, the mean annual sediment yield calculated according to Gavrilovic method so as to assess the risk of alluviation. Also, Kronfellner-Kraus method used in order to take under consideration the sediment that can flow into the lake after an extraordinary flood event. Finally, flood control works proposed so as minimize the threat of alluviation. The present study shows that the torrential environment (potential) is rather moderate, although during intense rainfalls great volume of water and debris discharge are produced so the only solution against alluviation is the construction of flood control works. Keywords: alluviation, flood control works, torrentional environment, watershed.
\end{abstract}

\section{INTRODUCTION}

Greece is a mountainous country with heavy rains, a small percentage of vegetation and vulnerable geological support. The result is the severe erosion and degradation of the numerous mountain rivers and streams flowing through them [1]. These torrents transport each year into the sea considerable quantities of sediment [2]. This activity has as consequences disastrous floods every year in the lowlands, while a powerful blow to the development and economy of these regions.

The prevention of erosion and degradation, and the arrangement of torrent and torrential streams for Greece is a key infrastructure project. The nature and extent of erosion are directly related with the intensity and composition of the transported sediment in the beds of streams and rivers. If these materials not cause a disaster at the plains, they are likely to come with the form of alluviations to the natural and technical barrages or to the sea.

Lake Volvi is important for the region because it provides water, irrigation, aquaculture, fisheries and recreation. The misuse or overuse of these benefits, however, undermines the proper management of the lake and the rational development of the region [3]. The basin of the lake is hilly in the northern mountainous regions, especially in the south. Therefore, numerous and significant torrents cross the basin. The lake, however, supplied by the torrents not only with water but also with abundantly sediments.

This research defines and describes the entire torrents environment (potential) of the surrounding area, specify the expected erosion and degradation of forest land and petrographic formations and finally suggest protection works against alluviation.

\section{BIBLIOGRAPHY REVIEW}

A major threat to natural lakes and artificial reservoirs is alluviation, caused by sediments that transported by torrents. Alluviation, as a consequence of increased sediment supply and decreased sediment 
transported capacity is a major threat to the biodiversity of the bedrock-controlled rivers which flow through the watersheds [4]. Reservoirs act as sediment traps, interrupting fluvial sediment transport by producing a quiescent pool into which inflowing solids are deposited. Without measures to balance sediment inflows, the reservoir's storage capacity, will be decreases to a significant degree [5-7]. Moreover, Psilovikos and Margoni [8] said that lakes and reservoirs are suffering from sediment deposition processes, which decrease their ability to conserve water for various intense purposes, lead to poor water management especially in flood episodes, pressure the aquatic ecosystems due to increased rates of evapotranspiration and effect the economy of the greater area. Hrissantou [9] quotes that reservoirs alluviation and sedimentation is closely associated with soil and bed erosion in the corresponding basin. Sediment inflow into reservoirs, through the river which feeds the reservoir, originates mainly from the products of soil and bed erosion in the corresponding basin. Greece demonstrates certain particularities such as a rather intense relief, uneven rainfall distribution during the year with intense rainfalls especially during autumn, small percentage of forest cover and a geological support that comprise highly erodible rocks [10]. These particularities produce several problems of erosion, alluviation and degradation of lakes and reservoirs. For the prevention against alluviation, it is necessary to apply the appropriate torrent control system with works at the mountainous watershed and at the plain beds [11].

\section{RESEARCH AREA}

The lake Volvi is the second biggest in extent lake of Greece. It is concretely found in Central Macedonia and inside the limits of Prefecture Thessaloniki, with geographic length $28^{\circ} 48^{\prime}$ and geographic width $40^{\circ} 68^{\prime}$. It is relatively shallow lake, tectonic origin and occupies the largest part of the Mygdonia basin (Fig. 1). It belongs to the category of fault lakes that is usually oblong and narrow and it occurs in fault valleys. Million years ago, the entire area of Mygdonia covered by water from a single lake remnant of which are Volvi and Koronia. The soils are alluvial, finegrained and relatively deep. It is supplied by waters from torrents of the mountains Holomontas Kerdyllia and Volvi as well as from surpluses of lake Koronia which are found $11 \mathrm{~km}$ westwards.

The banks are low and have an elongated shape with length of $21 \mathrm{~km}$ and width of $6 \mathrm{~km}$, the surface reaches $76 \mathrm{~km}^{2}$, while the bigger depth reaches $22 \mathrm{~m}$. The height level of the lake is $37 \mathrm{~m}$.

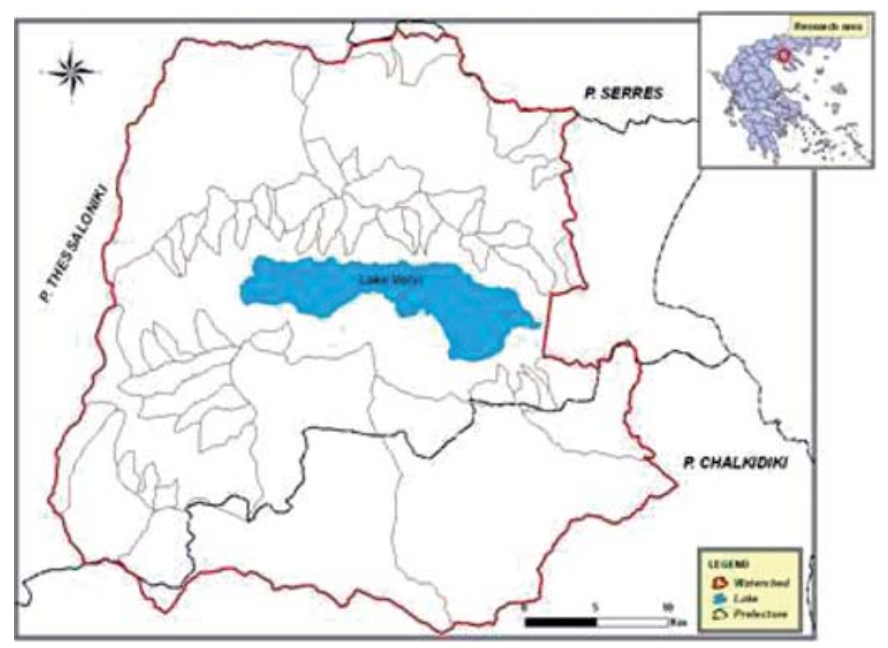

Figure 1: The research area. 
To ensure proper management of the lake Volvi was characterized as a wetland of international importance and special protection area under the Ramsar convention (Directive 79/409/E.E.) and specially protected area under the Barcelona convention.

\section{METEOROLOGICAL DATA}

As for the climate of the research area, we collect the meteorological data from six meteorological stations which are near the area. The meteorological stations are located at Arnaia, Taxiarxis, Zagliveri, Sohos, N. Apollonia and Arethousa area. The elevation of each one is presented in Table 1.

From the analysis of the meteorological data showed the mean annual and mean monthly precipitation and temperature (Tables 2 and 3).

\section{RESEARCH METHOD}

The methodology adopted for this research was conducted in ArcGIS following Stefanidis and Kalinderis [12]. Originally, the watersheds were designate and the hydrology network was surveyed from the detailed set of topographic map. In regard with the relief, a digital elevation model (DEM) was used and derived from the same set of topographic maps with 20 m contour's network. The most important morphometric attributes of the watershed which reflect their morphology and their water runoff were assessed [13].

The torrential environment of each watershed that relates to the type and intensity of torrentional phenomena which develop in mountainous watersheds was evaluated [14].

For drawing the map of land use patterns are digitized vegetation maps scales 1:200,000 of Thessaloniki and Chalkidiki prefectures by the Ministry of Agriculture. With regard to climate, data derived from the meteorological station of the wider area were taken into consideration.

The bedrock of the research area was derived from the detailed map of Institute of Geology and Mineral Exploration of Greece. The next procedure was the bedrock's classification according to Kotoulas theory on torrential petrographic formations $[15,16]$.

Annual sediment yield estimation considers factors related to surface soils, topography, average annual rainfall, temperature and land cover of the watershed. Initially, the erosion potential method calculates the sediment yield $(\mathrm{Z})$ by the following equation:

$$
\mathrm{Z}=\mathrm{x}^{*} \mathrm{y}^{*}\left(\varphi+\mathrm{J}^{1 / 2}\right)
$$

where $\mathrm{x}$ quantifies the protective nature of the land cover, $\mathrm{y}$ is a coefficient expressive soil resistance to erosion and $\mathrm{J}$ is the average slope of the watershed. The $\phi$ coefficient of observed erosion processes was evaluated by field observation of exposed rocks and bare soils from the available 1:50,000 soil map of the research area. The y coefficient was determined by the bedrock types provided from GIS

Table 1: The meteorological stations of the research area.

\begin{tabular}{llc}
\hline & Meteorological station & Elevation $(\mathrm{m})$ \\
\hline 1 & Arnaia & 585 \\
2 & Taxiarxis & 860 \\
3 & Zagliveri & 209 \\
4 & Sohos & 650 \\
5 & N. Apollonia & 90 \\
6 & Arethousa & 390 \\
\hline
\end{tabular}



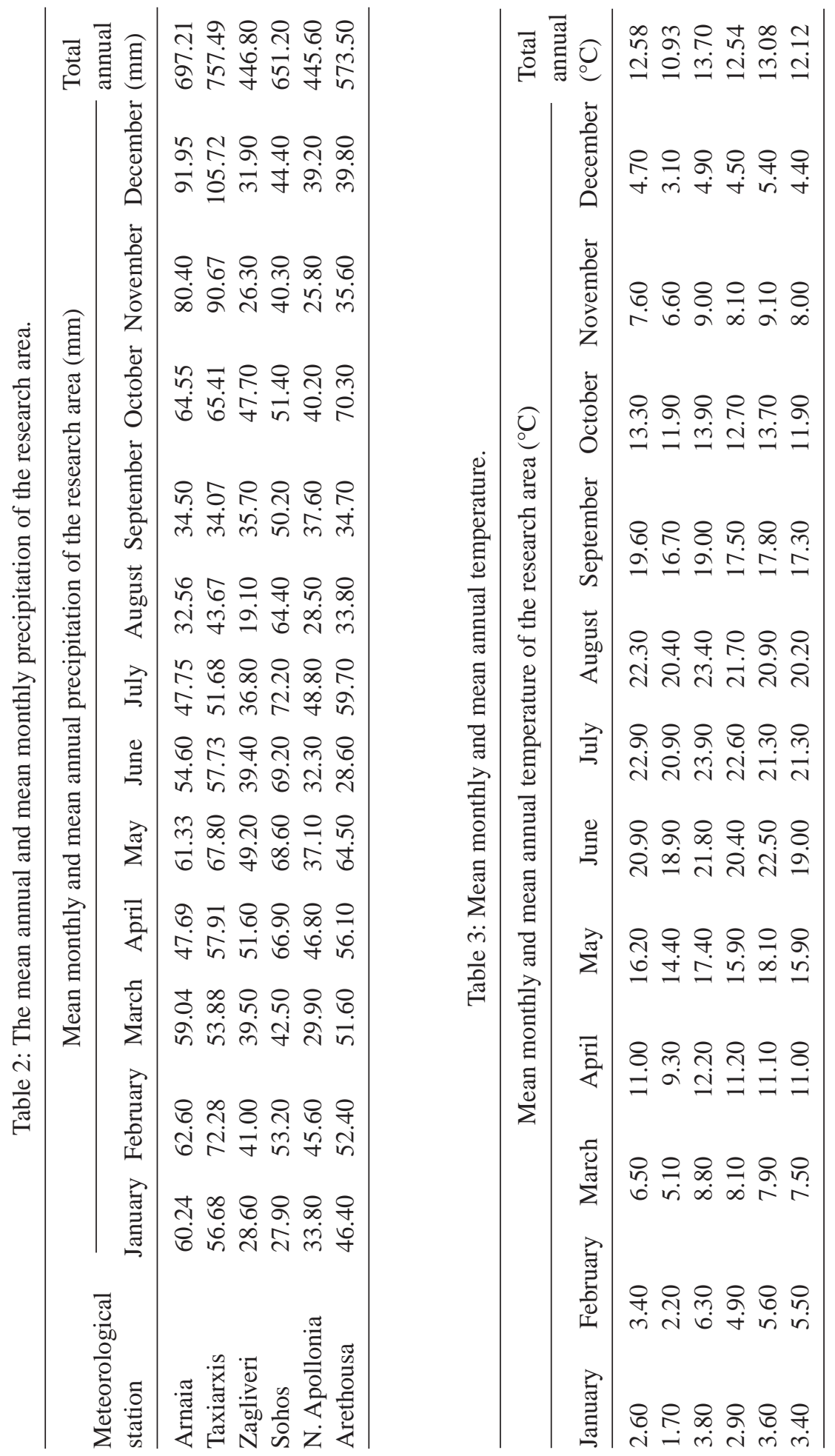
Table 4: Erosion category based on the mean value of coefficient Z.

\begin{tabular}{lcl}
\hline Erosion category & $\begin{array}{c}\text { Erosion potential } \\
\text { severity }\end{array}$ & \multicolumn{1}{c}{$\mathrm{Z}$ values } \\
\hline 1 & Severe & $0.8<\mathrm{Z}<1.0$ \\
2 & Heavy & $0.6<\mathrm{Z}<0.8$ \\
3 & Moderate & $0.4<\mathrm{Z}<06$ \\
4 & Slight & $\mathrm{Z}<0.4$ \\
\hline
\end{tabular}

format of geological maps. Furthermore, the coefficient of erosion and sediment yield (Z) was used to characterize potential erosion severity [17] within the watersheds according to classification scheme presented in Table 4.

Moreover, the assessment of the mean annual erosion and degradation on a watershed level was calculated by applying the erosion potential method or Gavrilovic method [18]. The calculation of the annual sediment yield $\mathrm{W}$ was estimated by:

$$
\mathrm{W}=\mathrm{T} * \mathrm{~h} * \pi * \mathrm{Z}^{1 / 2} * \mathrm{~F}\left(\mathrm{~m}^{3} / \mathrm{y}\right)
$$

where $\mathrm{W}$ is the average annual erosion within the watershed $\left(\mathrm{m}^{3} / \mathrm{y}\right), \mathrm{h}$ is the average annual height of precipitation $(\mathrm{mm} / \mathrm{y})$ and $\mathrm{T}$ is the temperature coefficient of the area calculated according to the average annual air temperature $\mathrm{t}^{\circ}\left({ }^{\circ} \mathrm{C}\right)$ :

$$
\mathrm{T}=\left(0.1 * \mathrm{t}^{\circ}+0.1\right)^{0.5}
$$

Furthermore, we use the method of Kronfellner-Kraus [19] to calculate the maximum sediment discharge general and especially at the small torrents of mountainous area that can be deposited at the cone of illuviation after an extraordinary flood phenomenon. The size of maximum total sediment in mountainous watersheds with expansion $80-120 \mathrm{~km}^{2}$ is given by:

$$
\mathrm{G}=\kappa^{*} \mathrm{~J} * \mathrm{~F}
$$

where $\mathrm{G}$ is the maximum total sediment $\left(\mathrm{m}^{3}\right), \mathrm{J}$ is the average slope of bed $(\%), \mathrm{F}$ is the area of the watershed $\left(\mathrm{Km}^{2}\right)$ and $\kappa$ is the coefficient which expressing the torrential potential.

The coefficient $\kappa$ is calculated as follows:

$$
\begin{aligned}
& \text { for very intensive torrential potential } \kappa=1750^{*}\left(1 / \mathrm{e}^{0.018^{*} \mathrm{~F}}\right) \\
& \text { for intensive torrential potential } \kappa=1150^{*}\left(1 / \mathrm{e}^{0.018^{*} \mathrm{~F}}\right) \\
& \text { for normal torrential potential } \kappa=540 *\left(1 / \mathrm{e}^{0.018^{*} \mathrm{~F}}\right) \\
& \text { and finally for slide torrential potential } \kappa=254^{*}\left(1 / \mathrm{e}^{0.018^{*} \mathrm{~F}}\right) \text {. }
\end{aligned}
$$

Finally, considering all the above factors suggested that the appropriate torrent control system with projects which will aim to prevent alluviation.

\section{RESULTS}

The research area found out that the grooved by 29 torrents covering an area of $70.30 \mathrm{~km}^{2}$. The maximum elevation reaches $1163 \mathrm{~m}$ while the minimum $50 \mathrm{~m}$. Basin mean slope takes values from 9.3\% to $44.7 \%$ and the mainstream mean slope takes values from $3.1 \%$ to $11.1 \%$. Regarding to the drainage density, it ranges from 1.3 to $11.1 \mathrm{~km} / \mathrm{km}^{2}$. The relief on the most of the watersheds characterized as abrupt. As a result, a rapid draining of surface flow is developed and thus, the increased kinetic energy produces the emergence of many types of erosion and hence the emergence of intense torrential phenomena. 


\subsection{Torrential environment}

The analysis of core torrential factors evaluated the torrential environment for the mountainous watersheds in the research area. In regard with bedrock, almost 65.8 of the research area consists of the magmatic formation and follows the sedimentary rocks with 23.84 , the limestone with $4.79 \%$, the schist formation with $3.83 \%$ and finally the alluvia deposits with $1.74 \%$.

The relief of the area was characterized as abrupt, while the average slopes of the watersheds were relatively high.

Concerning the land cover in the wider basin of the lake Volvi, almost $43.3 \%$ was shrubslands while the forested area occupy approximately $26.82 \%$, the agricultural crops $26.20 \%$, the grazing land $2.32 \%$ and the settlements $0.88 \%$.

In terms of climate, the region receives significant precipitation. The average annual rainfall is $596 \mathrm{~mm} / \mathrm{y}$ and the mean annual temperature is $12.49^{\circ} \mathrm{C}$.

\subsection{Soil erosion estimation with Gavrilovic method}

According to the classification based on the erosion coefficient $(\mathrm{Z})$ to erosion categories almost the $79 \%$ of the watersheds are classified in categories two and three (moderate and heavy) (Fig. 2). This is primarily due to the extensive cover of sedimentary rocks at the wider watershed and secondary to the steep terrain which is conducting to rapid runoff of surface water. The average annual soil loss is considered especially important. The watershed that produces the highest value of soil erosion per square kilometre is the watershed with id 24 where the erosion rates excess $930 \mathrm{~m}^{3} / \mathrm{y} / \mathrm{km}^{2}$ and the watershed with id 18.8 where the erosion rates excess $820 \mathrm{~m}^{3} / \mathrm{y} / \mathrm{km}^{2}$.

Table 5 represents the mean annual erosion, the mean annual special erosion and the mean coefficient $\mathrm{Z}$.

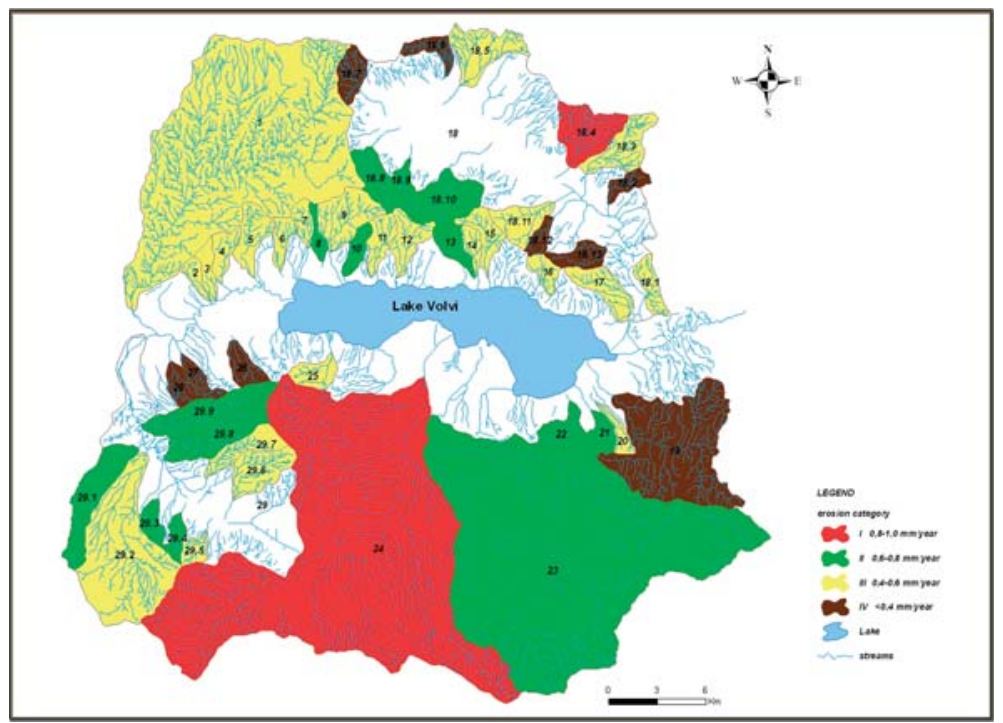

Figure 2: Erosion category, according to the erosion coefficient $\mathrm{Z}$. 


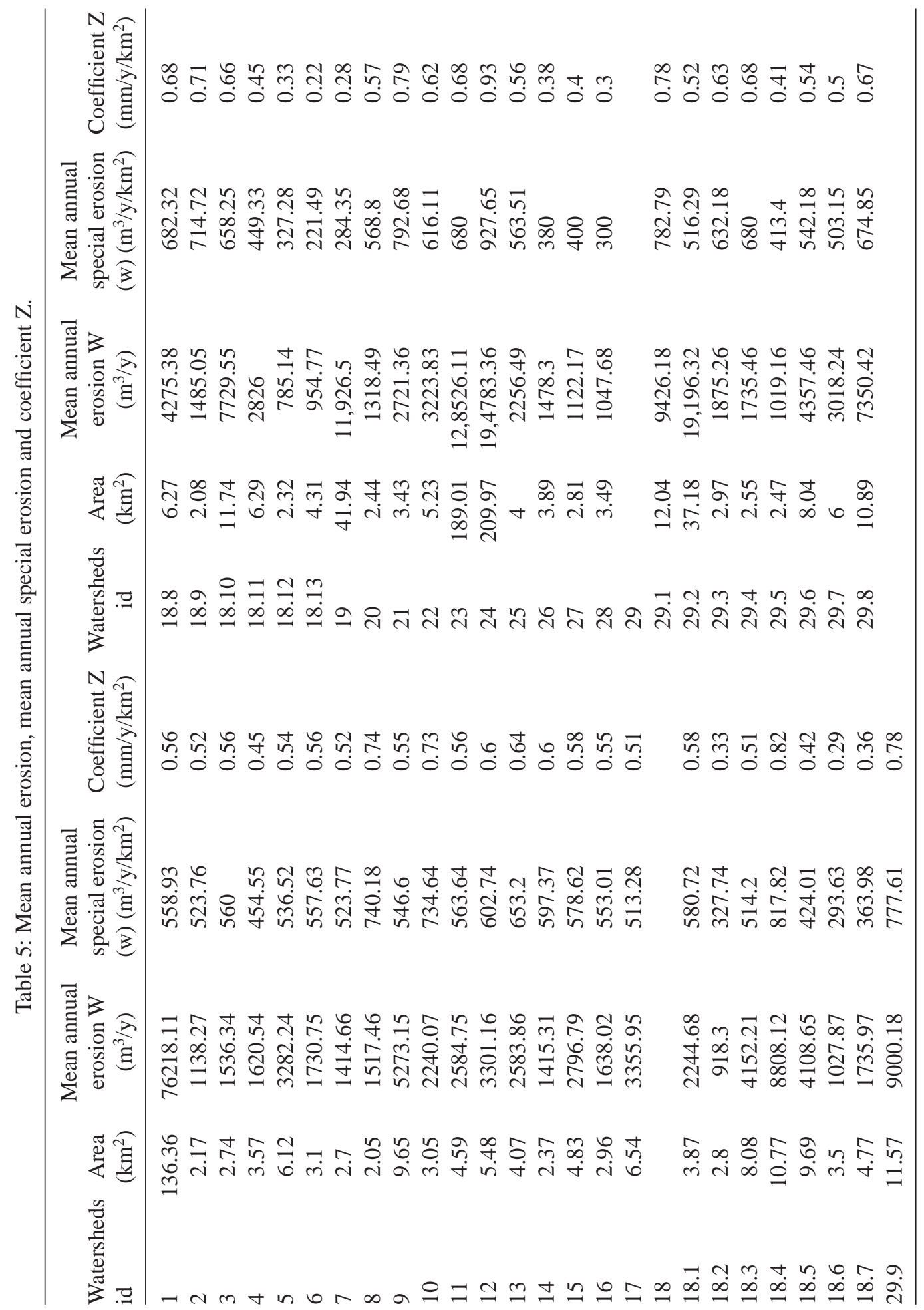


6.3 Estimation of sediment discharge with Kronfellner-Kraus method

After the application of Kronfellner-Kraus method at the research area, it emerges that the sediment discharge that can be deposited at the cone of illuviation in the winder watershed of the research area can threat the lake with alluviation due to the quantity of debris flow that entering into the lake (Table 6). From the results given the greater risk seems to have the watershed with id 24 where $\mathrm{G}$ is $82,491.18 \mathrm{~m}^{3}$ and follows the watershed with id 18.8 and 19 where $G$ takes values $83,895.19 \mathrm{~m}^{3}$ and $18,332.28 \mathrm{~m}^{3}$, respectively.

\subsection{Proposed flood control works}

From the collected studies and the recorded works which have been created for flood protection of the research area, it emerges that flood control works have not implemented in the torrents so as to

Table 6: Sediment discharge after flood phenomenon.

\begin{tabular}{lcccrc}
\hline Watershed id & Area $\left(\mathrm{km}^{2}\right)$ & $\mathrm{G}\left(\mathrm{m}^{3}\right)$ & Watershed id & Area $\left(\mathrm{km}^{2}\right)$ & $\mathrm{G}\left(\mathrm{m}^{3}\right)$ \\
\hline 1 & 136.36 & $100,371.6$ & 18.8 & 6.27 & $83,895.19$ \\
2 & 2.17 & 7149.819 & 18.9 & 2.08 & \\
3 & 2.74 & 9948.49 & 18.10 & 11.74 & $19,724.84$ \\
4 & 3.57 & $12,264.21$ & 18.11 & 6.29 & $10,842.77$ \\
5 & 6.12 & $18,115.21$ & 18.12 & 2.32 & 6912.612 \\
6 & 3.10 & $16,372.24$ & 18.13 & 4.31 & 7547.207 \\
7 & 2.70 & $15,563.01$ & 19 & 41.94 & $68,332.28$ \\
8 & 2.05 & $10,112.2$ & 20 & 2.44 & 7733.425 \\
9 & 9.65 & $40,971.9$ & 21 & 3.43 & $13,490.17$ \\
10 & 3.05 & $14,636.36$ & 22 & 5.23 & $18,732.96$ \\
11 & 4.59 & $26,747.94$ & 23 & 189.01 & $71,693.85$ \\
12 & 5.48 & $26,800.54$ & 24 & 209.97 & $82,491.81$ \\
13 & 4.07 & $24,237.22$ & 25 & 4.00 & $20,581.22$ \\
14 & 2.37 & $17,721.19$ & 26 & 3.89 & $28,423.59$ \\
15 & 4.83 & $25,177.45$ & 27 & 2.81 & $14,114.09$ \\
16 & 2.96 & $21,315.24$ & 28 & 3.49 & $18,573.43$ \\
17 & 6.54 & $16,373.68$ & 29 & & \\
18 & & & 29.1 & 12.04 & $46,167.42$ \\
18.1 & 3.87 & $16,176.65$ & 29.2 & 37.18 & $76,283.88$ \\
18.2 & 2.80 & $16,778.99$ & 29.3 & 2.97 & $15,252.73$ \\
18.3 & 8.08 & $39,996.11$ & 29.4 & 2.55 & $14,136.87$ \\
18.4 & 10.77 & $54,968.72$ & 29.5 & 2.47 & $18,144.35$ \\
18.5 & 9.69 & $21,379.67$ & 29.6 & 8.04 & $14,757.84$ \\
18.6 & 3.50 & $11,566.31$ & 29.7 & 6.00 & $11,808.13$ \\
18.7 & 4.77 & $31,456.63$ & 29.8 & 10.89 & $19,326.32$ \\
29.9 & 11.57 & $22,279.36$ & & & \\
\hline & & & & &
\end{tabular}




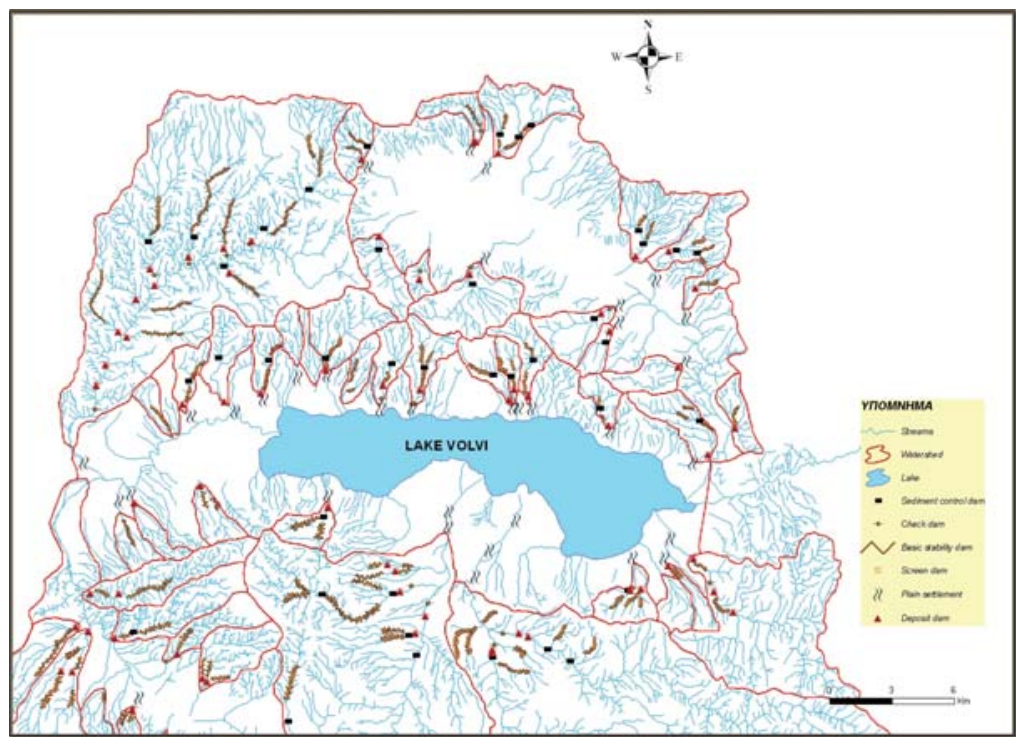

Figure 3: The proposed flood control works.

prevent flood genesis and the production of debris flow in the mountainous watersheds and the plain area of the torrents. Instead of these, only works at the plain beds have created in the torrents.

Taking under consideration the torrential environment, the erosion potential, the sediment discharge after flood phenomenon and the current situation of the wider watershed of the lake Volvi, it came out that the appropriate torrent control system for arrangement of the torrents that flow into the lake is the combined forest-techniques torrent control system.

The purpose of this system is the direct protection of the plain areas from the debris flow that deposited there and the check of the flood discharge for the protection of the works at the lowlands. This entire works will protect the lake Volvi from alluviation. The proposed works are check dams, screen dams, sediment control dams, basic stability dams, plain arrangement and deposit dams. Figure 3 represents the proposed works.

\section{DISCUSSION}

One of the most important hazards of natural and artificial lakes nowadays is their alluviation which leading to the complete disappearance of the lakes. According to other researches of Kotoulas [20], the average annual degradation in Greek watersheds reaches $0.65 \mathrm{~mm} / \mathrm{y}$. The evaluations of the degradation process in the research area produce a value of $0.67 \mathrm{~mm} / \mathrm{y}$. For this reason, the design of rational management of water resource is imperative and enforced based on the principle of sustainability.

The past years observed significant fall of level of the lakes in Greece, in our opinion is due to the torrents supplying the lakes with water and abundant debris. One example is the lake Koronia which has almost disappeared.

After the analysis of the torrentional environment of the wider watershed of the lake Volvi which is the research area and the estimation of the erosion and degradation from the transport of debris by the torrents that flow into the lake, we found that the alluviation threat is serious because the erosion 
rates excess $930 \mathrm{~m}^{3} / \mathrm{y} / \mathrm{km}^{2}$ and the quantity of sediment discharge that can be deposited at the cone of illuviation in the winder watershed of the research area excess $82,491.18 \mathrm{~m}^{3}$.

To protect the lake against alluviation, we concluded that the appropriate torrent control system is the combined forest-techniques system and the works that we suggest are: deposit dams, check dams, sediment control dams, screen dams and plain arrangement at the lowlands.

The intervention method and the works we suggest for the research area can constitute a model of intervention against lakes alluviation and it could also apply in other regions that threaten of the same risk.

\section{REFERENCES}

[1] Stefanidis, P., The torrent problems in Mediterranean areas (example from Greece). Proceedings of the IUFRO XX Congress. Finland, 1995.

[2] Zarris, D., Lykoudi, E. \& Koutsogiannis, D., Sediment yield estimation of a hydrological basin using measurements of reservoir deposits: a case study for the Kremasta reservoir, Western Greece. Proceedings of the 5th International Conference of European Water Resource Association: "Water Resources Management in the Era of Transition", Athens, pp. 338-345, 2002.

[3] Stefanidis, P., Stathis, D. \& Tziaftani, F., Estimation of the annual yield at the watershed of Modi with the Universal Soil Erosion Equation using GIS. Proceedings of the 13th Conference of the Hellenic Society of Forest Science: "Development of Mountainous Region - Protection of Natural Environment”, Kastoria, pp. 65-72, 2007.

[4] Rogers, K. \& Biggs, H., Integrating indicators, endpoints and value systems in strategic management of the rivers of the Kruger National Park. Freshwater Biology, 41(2), pp. 439-451, 1999. doi:http://dx.doi.org/10.1046/j.1365-2427.1999.00441.x

[5] Fan, J. \& Morris, G., Reservoirs sedimentation II: reservoir desiltation and long term storage capacity. Journal of Hydraulic Engineering, 118(3), pp. 373-384, 1992. doi:http://dx.doi. org/10.1061/(ASCE)0733-9429(1992)118:3(370)

[6] Verstraeten, G. \& Poesen, J., Estimating trap efficiency of small reservoirs and ponds: methods and implication for the assessment of sediment yield. Progress in Physical Geography, 24, pp. 219-251, 2000.

[7] Jain, S. \& Singh, P., Assessment of sedimentation in Bhakra reservoir in the western Himalayan region using remotely sensed data. Journal des Sciences Hydrologiques, 47(2), pp. 203-212, 2000. doi:http://dx.doi.org/10.1080/02626660209492924

[8] Psilovikos, A. \& Margoni, S., An empirical model of sediment deposition processes in Lake Kerkini, Central Macedonia Greece. Environmental Monitoring and Assessment, 164, pp. 573-592, 2010. doi:http://dx.doi.org/10.1007/s10661-009-0914-9

[9] Hrissanthou, V., Comparative application of two mathematical models to predict sedimentation in Yermasoyia Reservoir, Cyprus. Hydrological Processes, 20, pp. 3939-3952, 2006. doi:http://dx.doi.org/10.1002/hyp.6167

[10] Kotoulas, D. (eds), Mountainous Hydronomics I, Aristotle University of Thessaloniki, Department of Publications: Thessaloniki, 2001.

[11] Stiny, J., Die geologischen Grundlagen der Verbauung der Geschiebeherde, 1931.

[12] Stefanidis, P. \& Kalinderis, I., Estimation of the torrential environment (potential) of isle Zakynthos (Greece) using G.I.S. Proceedings of the 2nd International Conference on the River Basin Management, ed. C.A. Brebbia, WIT Press: Las Palmas, Gran Canaria, pp. 119-129, 2003.

[13] Horton, R.E., Drainage basin characteristics. Am. Geophys. Union Trans., 13, pp. 350-361, 1932. 
[14] Kotoulas, D., Die Wildbache Suddeutschalands und Griechenlands. Teil 1. Bericht Nr. 25. Munchen, 1972.

[15] Kotoulas, D., Torrents in Northern Greece, Readership Thesis, pp. 1-164, 1969.

[16] Stefanidis, P., Morphometrical and hydrographical composition of torrent types in Northern Greece. Scientific Annals of the Department of Forestry and Natural Environment. Appendix No. 6, Volume LB, pp. 239-262, 1990.

[17] Gavrilovic, Z., Stefanovic, M., Milovanovic, I., Cotric, J. \& Milojevic, M., Torrent classification - base of rational management of erosive regions. Proceedings of the XXIVth Conference of Dunabian Countries, Bled Slovenia, 2008.

[18] Gavrilovic, S., The use of an empirical method (Erosion Potential Method) for calculating sediment production and transportation in unstudied or torrential streams. International Conference on River Regime, ed. W.R. White, Wiley: New York, pp. 411-422, 1988.

[19] Kronfellner-Kraus, G., Quantitative estimation of torrent erosion. Proceedings of the International Symposium on Erosion, Debris Flow and Disaster Prevention, ed. T. Aritsune, Tsukuba, Japan, pp. 107-110, 1985.

[20] Kotoulas, D., Denudation and sedimentation in Greece as an example - from the mountains and the plain of Salonica. International Symposium of INTERPRAEVENT, Villach, pp. 343-353, 1984. 